Jurnal Health Sains: p-ISSN: 2723-4339 e-ISSN: 2548-1398

Vol. 2, No. 6, Juni 2021

\title{
ISOLASI DAN IDENTIFIKASI SENYAWA FLAVONOID PADA TANAMAN
}

\author{
Audi Ichsani Aribowo, Christina Febiola Lubis, Lestari Mahardika Urbaningrum, Nurma \\ Dwi Rahmawati, Sridevi Anggraini \\ Universitas Singaperbangsa Karawang (UNSIKA) Jawa Barat, Indonesia \\ Email: audiichsania@gmail.com, christinafebiola.lubis@gmail.com, lestaribing17@gmail.com, \\ nurmadwi23@gmail.com, sridevianggraini27@gmail.com
}

\begin{tabular}{ll}
\hline ARTIKEL INFO & ABSTRACT \\
\hline Diterima: 5 Juni 2021 & Isolation of flavonoid compounds can be done in various \\
Direvisi: 15 Juni 2021 & stages. In this study, a literature study was done to determine \\
Disetujui: 25 Juni 2021 & the procedure for the Isolation and Identification of \\
\hline Keywords: & Flavonoid Compounds. The procedure usually begins with a \\
isolation; flavonoids; & phytochemical test (screening) first. Flavonoid \\
extraction; fractionation; & phytochemical tests can be done with various types of tests, \\
identification; secondary & Bate Smith-Matcalfe test, 10\% NaOH test, and Wilstatter \\
metabolites. & test. It can be done with all of the tests or just one of them. \\
& The first step is extraction with a suitable solvent. The \\
& suitable solvents for the isolation of flavonoid compounds are \\
& polar and semi-polar solvents. Extraction of plant \\
& compounds for isolated flavonoid compounds used the \\
& maceration method. Maceration carried out for 72 hours \\
& while stirring every 24 hours. After that the extract was \\
& concentrated with a rotary vacuum evaporator. The next step \\
is fractionation. For the fractionation of isolated flavonoid \\
compounds, it can be done by the methods of Liquid-Liquid \\
Extraction, Vacuum Liquid Chromatography, Column \\
Chromatography, and Thin Layer Chromatography. Solvents \\
that can be used in this step vary, depending on the method. \\
Then, isolate be monitored to determine the type of flavonoid \\
contained in the isolate. The methods that can be used in this \\
step are UV-Vis Spectrophotometer, HNMR, and FTIR \\
spectrophotometer. You can use one method or two methods.
\end{tabular}

\begin{abstract}
ABSTRAK
Isolasi dan identifikasi senyawa flavonoid dilakukan dalam berbagai tahap. Pada penelitian kali ini, dilakukan studi literatur untuk mengetahui bagaimana prosedur Isolasi dan Identifikasi Senyawa Flavonoid. Prosedur biasanya diawali dengan uji fitokimia (skrining) dahulu. Uji fitokimia flavonoid dapat dilakukan dengan berbagai jenis uji, uji Bate Smith-Matcalfe, uji dengan $\mathrm{NaOH} 10 \%$, dan uji Wilstatter. Bisa dilakukan ketiganya atau hanya salah satunya. Tahap pertama adalah ekstraksi dengan pelarut sesuai. Pelarut yang sesuai untuk isolasi senyawa flavonoid adalah pelarut polar dan semi-polar. Ekstraksi senyawa tanaman untuk isolasi flavonoid digunakan metode maserasi. Maserasi dilakukan selama 72 jam sambil dilakukan pengadukan setiap 24 jam.

Setelah itu ekstrak dipekatkan dengan alat rotary vacum
\end{abstract}

$\begin{array}{ll}\text { How to cite: } & \text { Aribowo, Audi Ichsani. et, al. (2021) Isolasi dan Identifikasi Senyawa Flavonoid pada Tanaman. Jurnal } \\ & \text { Health Sains 2(6). https://doi.org/10.46799/jhs.v2i6.188 } \\ \text { E-ISSN: } & \text { 2723-6927 } \\ \text { Published by: } & \text { Ridwan Institute }\end{array}$


Kata Kunci:

isolasi; flavonoid; ekstraksi; fraksinasi; identifikasi; metabolit sekunder. evaporator. Tahap selanjutnya yaitu fraksinasi. Untuk fraksinasi dalam isolasi senyawa flavonoid, dapat dilakukan dengan metode Ekstraksi Cair-Cair, Kromatografi Cair Vakum, Kromatografi Kolom, dan Kromatografi Lapis Tipis. Pelarut yang dapat digunakan dalam tahap ini bermacammacam, tergantung dari metode yang digunakan. Selanjutnya dilakukan identifikasi isolat untuk mengetahui jenis flavonoid yang terdapat pada isolat. Metode yang dapat digunakan dalam tahap ini adalah Spektrofotometer UV-Vis, H-NMR, dan spektrofotometer FTIR. Bisa dengan satu metode ataupun dua metode.

\section{Pendahuluan}

Indonesia terkenal akan potensinya sebagai rumah terhadap tanaman obat. Hal ini dibuktikan dari 40.000 tanaman obat yang telah ditemukan di seluruh dunia, sekitar 30.000 jenisnya terdapat di Indonesia. Di Asia saja, Indonesia memiliki sekitar $90 \%$ tanaman obat yang terdapat di seluruh Asia. Meskipun begitu, diperkirakan hanya ada sekitar 9.000 jenis tanaman yang betul memiliki khasiat sebagai obat.

Tanaman Obat sendiri menjadi populer belakangan ini karena maraknya tren back to nature. Masyarakat beramai-ramai mengubah pengobatan mereka ke bahan alam karena dinilai memberikan efek samping yang lebih sedikit. Tanaman Obat sendiri diketahui memiliki efek preventif dan promotif terhadap tubuh. Hal ini dikarenakan pada tanaman obat diketahui ada kandungan metabolit sekunder yang dapat meningkatan daya tahan tubuh. Salah satu metabolit sekunder tersebut adalah Flavonoid (Salim \& Pranata, 2017).

Flavonoid adalah salah satu senyawa metabolit sekunder yang terdapat dalam semua tumbuhan hijau (Nuari \& Widayati, 2017). Flavonoid termasuk ke dalam golongan polifenol dan memiliki efek farmakologi sebagai antioksidan, antipenuaan, anti-inflamasi, anti-virus, dan lainnya (Hepni, 2019).

Berdasarkan penelitian di atas, maka dilakukanlah studi literatur mengenai isolasi dan identifikasi senyawa flavonoid pada tanaman, seperti buah belimbing wuluh (Averrhoa bilimbi L.), buah naga merah (Hylocereus polyrhizus), batang senggani (Melastoma malabathricum L.), dan berbagai tanaman lainnya. Hasil isolasi metabolit sekunder tertentu nantinya berguna sebagai informasi mengenai kandungan senyawa pada tanaman atau bagian tanaman tertentu. (Hamdanah et al., 2015).

\section{Metode Penelitian}

Metode penelitian kali ini dilakukan dengan literature pada artikel ilmiah yang berkaitan dengan Isolasi dan Identifikasi Senyawa Flavonoid pada tanaman.

\section{Hasil dan Pembahasan}

1. Skrining

Skrining senyawa metabolit flavonoid atau uji fitokimia flavonoid dapat dilakukan setelah dibuat ekstrak bagian tanaman dengan pelarut yang sesuai. Selain itu juga uji fitokimia dapat dilakukan pada ekstrak hasil partisi. Ada tiga metode yang dapat dilakukan untuk mengetahui ada atau tidak adanya kandungan flavonoid pada suatu ekstrak tanaman. Metode tersebut di antaranya adalah Uji Wilstatter, Uji Bate SmithMatcalfe, dan Uji dengan $\mathrm{NaOH} 10 \%$. Dalam melakukan skrining flavonoid atau uji fitokimia flavonoid pada ekstrak tanaman, peneliti dapat melakukan tiga uji 
sekaligus ataupun memilih salah satunya, seperti pada penelitian isolasi senyawa flavonoid pada fraksi etil asetat batang tumbuhan senggani atau Melastoma malabathricum L. (R. Aisyah \& Destiarti, 2018) dan ekstrak batang tumbuhan mengkudu atau Morinda citrifolia $L$. (Rahmawati, 2017).

a. Uji Wilstatter

Pada uji wilstatter, sampel yang akan diuji atau ekstrak tanaman ditaruh di dalam tabung kemudian ditambahkan serbuk Magnesium dan 2 hingga 4 tetes Asam Klorida $(\mathrm{HCl})$ pekat. Setelah itu tabung dikocok. Ekstrak tanaman dinyatakan positif flavonoid kelompok flavonol dan flavanon apabila terjadi perubahan warna menjadi merah. Perubahan warna ini dapat terjadi karena terbentuknya garam benzopirilium yang berwarna merah sebagai akibat dari tereduksinya gugus polihidroksi dari flavonol oleh magnesium dalam asam klorida.

b. Uji Bate Smith-Matcalfe

Pada Uji Bate Smith-Matcalfe, sampel yang akan diuji atau ekstrak tanaman yang terdapat di dalam tabung ditambahkan Asam Sulfat (H2SO4) pekat, lalu tabung dipanaskan di atas waterbath. Sampel dinyatakan positif flavonoid antosianidin apabila terjadi perubahan warna menjadi jingga. Hal ini dikarenakan karena $\mathrm{H} 2 \mathrm{SO} 4$ atau secara umum asam kuat, akan menghidrolisis dan mengubah antosianin menjadi antosianidin yang nantinya akan membentuk warna jingga. Panas disini berfungsi untuk mempercepat terjadinya reaksi tersebut.

c. Uji dengan $\mathrm{NaOH} 10 \%$

Pada uji kandungan flavonoid dengan $\mathrm{NaOH} 10 \%$, ekstrak tanaman yang akan diuji ditetesi larutan $\mathrm{NaOH}$ 10\%. Apabila ekstrak tanaman mengalami perubahan warna menjadi merah hingga coklat, maka sampel dinyatakan positif flavonoid golongan fenol. Hal ini dapat terjadi karena terbentuknya senyawa asetofenon saat sampel direaksikan dengan $\mathrm{NaOH}$. (Bona et al., 2015).

\section{Ekstraksi}

Ekstraksi adalah suatu teknik pemisahan zat aktif dari campurannya dengan bantuan pelarut yang sesuai. Terdapat macam-macam metode ekstraksi yaitu, metode ekstraksi konvensional dan metode ekstraksi modern. Pada metode ekstraksi konvensional terdapat metode maserasi dan refluks. Sedangkan metode esktraksi modern terdapat ekstraksi Microwave Assisted Extraction (MAE) dan Ultrasound Assisted Extraction (UAE) (T Nur Haliza et al., 2020). Metode ekstraksi digunakan untuk menentukan jumlah zat aktif yang dapat tersari sehingga dilakukan penelitian ini untuk menghasilkan ekstrak kental untuk mengidentifikasi senyawa flavonoid dengan metode maserasi. Maserasi adalah suatu metode pengekstrakan simplisia menggunakan bantuan pelarut dengan beberapa kali pengadukan pada temperatur ruangan dengan waktu perendaman $3 \times 24$ jam. Dalam penelitian ini, pembuatan ekstraksi simplisia dibuat dalam bentuk serbuk, dirajang, maupun bagian dari simplisia langsung di maserasi menggunakan pelarut yang sesuai. Jenis pelarut yang berbeda digunakan peneliti dalam metode maserasi yaitu etanol $70 \%$, etanol $80 \%$, aseton $96 \%$, n-heksan dan methanol dengan rata-rata waktu perendaman $3 \times 24$ jam pada suhu $40-70^{\circ} \mathrm{C}$. Sebagian peneliti menggunakan pelarut etanol sebagai pelarut pada simplisia yang akan di maserasi. Pemilahan etanol sebagai pelarut digunakan kerena etanol memiliki sifat yang lebih selektif pada senyawa metabolit sekunder, tidak cepat 
ditumbuhi oleh jamur dan bakteri, tidak mengandung racun, tidak terjadi reaksi dengan komponen zat yang akan di ekstraksi, penyerapannya baik, tidak memerlukan waktu lama dalam membuat ekstrak kental (Sa'adah \& Nurhasnawati, 2017). Kemudian pelarut etanol juga merupakan pelarut polar yang dapat mengekstraksi senyawa flavonoid yang merupakan senyawa polar juga sehingga senyawa flavonoid akan lebih mudah larut (Markham, 1988). Adapun peneliti yang menggunakan $\mathrm{n}$-heksan sebagai pelarut untuk memisahkan senyawa-senyawa nonpolar untuk memudahkan mendapatkan senyawa flavonoid. Senyawa flavonoid bersifat tidak tahan terhadap proses pemanasan dan cepat teroksidasi pada suhu tinggi, oleh karena itu digunakannya metode ekstraksi maserasi (Wang et al., 2006). Setelah dilakukan maserasi ekstraksi dipekatkan menggunakan rotary evaporator untuk mendapatkan ekstraksi kental

3. Fraksinasi

Fraksinasi adalah metode pemisahan ekstrak berdasarkan kepolaran (Akhsanita, 2012). Fraksinasi ini menggunakan dua pelarut yang tidak tercampur dan memiliki tingkat kepolaran yang berbeda (Akhsanita, 2012). Tujuan dari fraksinasi adalah untuk memisahkan senyawa berdasarkan kepolarannya, sehingga jumlah dan jenisnya menjadi fraksi berbeda (Bona et al., 2015). Pelarut yang biasa digunakan pada fraksi senyawa flavonoid adalah n-heksana dan etil asetat. Fraksinasi dapat dilakukan dengan metode ektraksi cair-cair dan kromatografi. Metode kromatografi yang biasa digunakan pada isolasi senyawa flavonoid adalah kromatografi cair vakum (KCV), kromatografi kolom (KK), dan kromatografi lapis tipis (KLT).

a. Ekstraksi Cair Cair
Ekstrak dilarutkan dalam air lalu ditambahkan pelarut n-heksana, lalu dikocok dan didiamkan hingga terdapat dua lapisan yang terpisah selama \pm 30 menit. Kemudian pada sisa dari proses partisi n-heksana ditambahkan dengan etil asetat, sehingga diperoleh fraksi etil asetat dan fraksi air. Hasil dari lapisan etil asetat dipekatkan menggunakan rotary evaporator hingga diperoleh fraksi etil asetat, sisa fraksinasi (fraksi air) juga di pekatkan sehingga diperoleh fraksi air (Hepni, 2019). Fraksi yang positif mengandung flavonoid, selanjutkan diisolasi dan diuji pemurnian (Hepni, 2019).

b. Kromatografi Cair Vakum (KCV)

Ekstrak etil asetat ditambahkan pelarut dan silika gel secukupnya, lalu diaduk hingga homogen dan menjadi serbuk kering. Kemudian fase gerak dimasukkan pada kolom yang telah ditekan agar menjadi padat dengan tingkat kepolarannya secara gradien, yaitu n-heksana 100\% (2 kali), nheksana:etil asetat (8:2), (6:4), (4:6), $(2: 8)$ etil asetat $100 \%$, etil asetat:metanol (1:1), dan metanol (Nuari \& Widayati, 2017).

c. Kromatografi Kolom (KK)

Silika gel dikeringkan terlebih dahulu menggunakan oven dengan suhu $105^{\circ} \mathrm{C}$ selama 4 jam, lalu didinginkan untuk mengaktivasi dan mengurangi kadar air dalam silika tersebut, kemudian ditambahkan dengan sedikit fase gerak hingga berbentuk seperti bubur. Selanjutnya fase gerak dimasukkan ke bagian bawah kolom yang tersumbat kapas. Kecepatan aliran pelarut dalam kolom diatur dan bubur dimasukkan sedikit demi sedikit. Lalu fase diam dielusi hingga padat sempurna. Ekstrak ditambahkan dengan pelarutnya kemudian dimasukkan tepat pada atas 
tengah bagian kolom, sementara aliran fase gerak diatur $1 \mathrm{~mL} /$ menit. Setelah sampel masuk ke dalam fase diam, fase gerak ditambahkan secara terus menerus hingga terjadi pemisahan. Setiap $3 \mathrm{ml}$, eluat ditampung pada penampung fraksi.

d. Kromatografi Lapis Tipis

Ekstrak ditambahkan pelarut, lalu ditotolkan pada plat KLT dan diletakkan pada bejana yang telah dijenuhkan dengan eluen. Plat KLT dibiarkan dalam bejana hingga eluen sampai pada batas yang ditentukan. Setelah itu dikeluarkan dari bejana dan dikering anginkan, lalu disinari dengan lampu ultraviolet $254 \mathrm{~nm}$.

4. Identifikasi Senyawa Flavonoid

$$
\text { Untuk identifikasi senyawa }
$$

flavonoid, isolate dipantau dengan spektromoter UV-Vis dan dengan H-NMR (Satolom, 2015). Dapat juga diidentifikasi dengan spektromoter FTIR (Maulana et al., 2016) atau hanya diidentifiikasi dengan spektromoter UV-Vis (Hepni, 2019; Ritna et al., 2016). Hasil analisis spektrofotometri UV/Vis menggunakan pelarut methanol memikili serapan maksimum dengan panjang gelombang pita I yaitu $271,2 \mathrm{~nm}$ dan pita II yaitu 272,2 nm (Hepni, 2019). Selaras dengan penelitian lain yang memberikan panjang gelombang pada pita I yaitu $365 \mathrm{~nm}$ sedangkan pita II yaitu $280 \mathrm{~nm}$ diduga senyawa flavonoid golongan flavonol (Bona et al., 2015). Sedangkan pada isolate 3 diduga senyawa flavonoid golongan flavanon atau hidroflavonol dengan menunjukkan serapan maksimum dengan panjang gelombang yaitu $330 \mathrm{~nm}$ pada pita 1 dan $280 \mathrm{~nm}$ pada pita 2 (Nuari $\&$ Widayati, 2017).

Setelah itu menambahkan pereaksi geser seperti $\mathrm{AlCl} 35 \%, \mathrm{NaOH} 2 \mathrm{M}$, $\mathrm{CH} 3 \mathrm{COONa}$, dan $\mathrm{CH} 3 \mathrm{COONa} / \mathrm{H} 3 \mathrm{BO} 3$, untuk mengetahui kedudukan gugus hidroksi dengan cara mengamati pergerseran batokromik yaitu absorban mengarah ke daerah panjang gelombang yang lebih panjang atau pergerseran hipsokromik yaitu pergeseran panjang gelombang lebih pendek hal ini dikarenakan terdapat substitusi sebagai efek pelarut. Saat penambahan pereaksi geser $\mathrm{NaOH} 2 \mathrm{M}$ terdapat pergeseran batokhoromik mengarah ke arah kiri 15 $\mathrm{nm}$ yaitu $10 \mathrm{~nm}$ untuk pita I dan $5 \mathrm{~nm}$ untuk pita II yang menunjukkan bahwa isolate memiliki gugus hidroksil pada posisi 3,4'-OH dicincin B dan membentuk O-diOH atau orto-dihidroksi. Ketika ditambahkan pereaksi geser $\mathrm{AlCl} 35 \%$ mengalami pergeseran sebesar $45 \mathrm{~nm}$ yang menunjukkan gugus hidroksi posisi 3' dan 4' terdapat gugus O-diOH. Selanjutnya diberikan pereaksi geser $\mathrm{CH} 3 \mathrm{COONa}$ menunjukkan adanya pergeseran dengan panjang sebesar $20 \mathrm{~nm}$ yaitu memiliki gugus 7-OH dan terdapat oksigenasi pada C8 atau C6. Terakhir isolate diberi pereaksi $\mathrm{CH} 3 \mathrm{COONa} / \mathrm{H} 3 \mathrm{BO} 3$ terjadi pergeseran ke kanan yaitu $15 \mathrm{~nm}$ hal ini menunjukkan bahwa terdapat gugus $\mathrm{O}$ diOH dicincin A yaitu 6,7 atau 7,8 (Bona et al., 2015).

Kemudian dilanjutkan pada pengidentifikasi dengan spektromoter FTIR menggunakan pelarut aseton: air yang bersifat polar menghasilkan sprektra IR menunjukkan adanya gugus-gugus yaitu vibrasi ulur gugus dengan bilangan gelombang 3443,9 cm-1 menunjukkan serapan $\mathrm{O}-\mathrm{H}$, terdapat serapan cincin $\mathrm{C}=\mathrm{C}$ aromatic pada bilangan gelombang 1367,9 cm-1, kemudian terlihat serapan $\mathrm{C}=\mathrm{O}$ pada bilangan gelombang $1648,3 \mathrm{~cm}-1$ dan menunjukkan serapan C-O-C pada bilangan gelombang 1060,3 cm-1 (Bona et al., 2015).

Sedangkan pada identifikasi menggunakan spectrum H-NMR pada fraksi 4 terlihat ada 2 kelompok 
Audi Ichsani Aribowo, Christina Febiola Lubis, Lestari Mahardika Urbaningrum, Nurma Dwi Rahmawati, Sridevi Anggraini

pergeseran kimia pada 1-4 ppm yang kemungkinan menunjukkan daerah pergeseran pengotor dan pergeseran 6-8 ppm menunjukkan gugus aromatic dari aglikon flavonoid (H. A. Aisyah et al., 2019).

\section{Kesimpulan}

Berdasarkan pokok bahasan yang telah dibahas, isolasi dan identifikasi senyawa flavonoid pada tanaman memiliki berbagai metode seperti: skrining, ekstraksi, fraksinasi dan identifikasi senyawa. Terdapat tiga metode skrining yaitu Uji Wilstatter, Uji Bate Smith-Matcalfe, dan Uji dengan $\mathrm{NaOH} 10 \%$. Pada ekstraksi menggunakan metode maserasi. Fraksinasi dapat dilakukan dengan metode ektraksi cair-cair, kromatografi cair vakum (KCV), kromatografi kolom (KK), dan kromatografi lapis tipis (KLT). Identifikasi senyawa flavonoid, dapat menggunakan spektromoter UV-Vis dan dengan H-NMR, spektromoter FTIR, atau hanya dengan spektromoter UV-Vis. Hasil isolasi ditemukan adanya senyawa metabolit sekunder flavonoid.

\section{BIBLIOGRAFI}

Aisyah, H. A., Paridah, M. T., Sapuan, S. M., Khalina, A., Berkalp, O. B., Lee, S. H., Lee, C. H., Nurazzi, N. M., Ramli, N., \& Wahab, M. S. (2019). Thermal Properties Of Woven Kenaf/Carbon Fibre-Reinforced Epoxy Hybrid Composite Panels. International Journal Of Polymer Science, 2019. Google Scholar

Aisyah, R., \& Destiarti, L. (2018). Isolasi Dan Karakterisasi Senyawa Flavonoid Dari Fraksi Etil Asetat Batang Tumbuhan Senggani (Melastoma Malabathricum L.). Jurnal Kimia Khatulistiwa, 8(2). Google Scholar

Akhsanita, M. (2012). Uji Sitotoksik Ekstrak, Fraksi, Dan Sub-Fraksi Daun Jati
(Tectona Grandis Linn. F.) Dengan Metoda Brine Shrimp Lethality Bioassay [Skripsi]. Padang: Fakultas Farmasi Universitas Andalas. Google Scholar

Bona, A. Della, Pecho, O. E., \& Alessandretti, R. (2015). Zirconia As A Dental Biomaterial. Materials, 8(8), 4978-4991. Google Scholar

Hamdanah, S., Anam, S., \& Jamaluddin, J. (2015). Isolasi Dan Identifikasi Senyawa Flavonoid Dari Ekstrak Etanol Buah Belimbing Wuluh (Averrhoa Bilimbi L.) Dengan Metode Spektrofotometri UvVis. Jurnal Farmasi Galenika (Galenika Journal Of Pharmacy)(E-Journal), 1(1), 22-34. Google Scholar

Hepni, H. (2019). Isolasi Dan Identifikasi Senyawa Flavonoid Dalam Daun Kumak (Lactuca Indica L.). Jurnal Dunia Farmasi, 4(1), 17-22. Google Scholar

Markham, K. R. (1988). Distribution Of Flavonoids In The Lower Plants And Its Evolutionary Significance. In The Flavonoids (Pp. 427-468). Springer. Google Scholar

Maulana, R., Opdenakker, M.-C., \& Bosker, R. (2016). Teachers' Instructional Behaviors As Important Predictors Of Academic Motivation: Changes And Links Across The School Year. Learning And Individual Differences, 50, 147-156. Google Scholar

Nuari, N. A., \& Widayati, D. (2017). Gangguan Pada Sistem Perkemihan \& Penatalaksanaan Keperawatan. Deepublish. Google Scholar

Rahmawati, N. K. (2017). Implementasi Teams Games Tournaments Dan Number Head Together Ditinjau Dari Kemampuan Penalaran Matematis. AlJabar: Jurnal Pendidikan Matematika, 8(2), 121-134. Google Scholar

Ritna, A., Anam, S., \& Khumaidi, A. (2016). 
Identifikasi Senyawa Flavonoid Pada Fraksi Etil Asetat Benalu Batu (Begonia Sp.) Asal Kabupaten Morowali Utara. Jurnal Farmasi Galenika (Galenika Journal Of Pharmacy)(E-Journal), 2(2), 83-89. Google Scholar

Sa'adah, H., \& Nurhasnawati, H. (2017). Perbandingan Pelarut Etanol Dan Air Pada Pembuatan Ekstrak Umbi Bawang Tiwai (Eleutherine Americana Merr) Menggunakan Metode Maserasi. Jurnal Ilmiah Manuntung, 1(2), 149-153. Google Scholar

Salim, Z., \& Pranata, N. (2017). Maritime Logistics Sector In Asean: Exploring Opportunities And Addressing Key Challenges. Asean Briefs. Google Scholar

Satolom, C. C. (2015). Isolasi Senyawa Flavonoid Pada Biji Pinang Yaki (Areca Vestiaria Giseke). Jurnal Mipa, 4(1), 40-45. Google Scholar

T Nur Haliza, I., Yuliansyah Sundara Mulia, Y., Novi Utami Dewi, N., \& Yeni Wahyuni, Y. (2020). Stabilitas

\section{Copyright holder:}

Audi Ichsani Aribowo, Christina Febiola Lubis, Lestari Mahardika Urbaningrum, Nurma Dwi Rahmawati, Sridevi Anggraini (2021)

\section{First publication right:}

Jurnal Health Sains

This article is licensed under: 